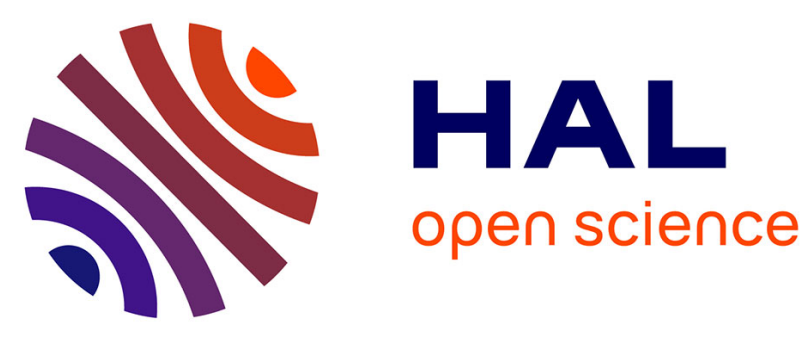

\title{
Statistical Analysis of the Influence of Some Trace Elements on Chunky Graphite Formation in Heavy Section Nodular Iron Castings
}

\author{
Jon Sertucha, Jacques Lacaze, Susana Armendariz, Peio Larrañaga
}

\section{To cite this version:}

Jon Sertucha, Jacques Lacaze, Susana Armendariz, Peio Larrañaga. Statistical Analysis of the Influence of Some Trace Elements on Chunky Graphite Formation in Heavy Section Nodular Iron Castings. Metallurgical and Materials Transactions A, 2013, vol. 44 ( $\left.{ }^{\circ} 3\right)$, pp. 1159-1162. 10.1007/s11661012-1592-8 . hal-01170437

\section{HAL Id: hal-01170437 \\ https://hal.science/hal-01170437}

Submitted on 1 Jul 2015

HAL is a multi-disciplinary open access archive for the deposit and dissemination of scientific research documents, whether they are published or not. The documents may come from teaching and research institutions in France or abroad, or from public or private research centers.
L'archive ouverte pluridisciplinaire HAL, est destinée au dépôt et à la diffusion de documents scientifiques de niveau recherche, publiés ou non, émanant des établissements d'enseignement et de recherche français ou étrangers, des laboratoires publics ou privés. 


\section{OATAO \\ Open Archive Toulouse Archive Ouverte}

\section{Open Archive TOULOUSE Archive Ouverte (OATAO)}

OATAO is an open access repository that collects the work of Toulouse researchers and makes it freely available over the web where possible.

This is an author-deposited version published in : http://oatao.univ-toulouse.fr/ Eprints ID : 14063

To link to this article : DOI:10.1007/s11661-012-1592-8

URL : http://dx.doi.org/10.1007/s11661-012-1592-8

To cite this version : Sertucha, Jon and Lacaze, Jacques and Armendariz, Susana and Larrañaga, Peio Statistical Analysis of the Influence of Some Trace Elements on Chunky Graphite Formation in Heavy Section Nodular Iron Castings. (2013) Metallurgical and Materials Transactions A, vol. 44 (n 3). pp. 1159-1162. ISSN 10735623

Any correspondance concerning this service should be sent to the repository administrator: staff-oatao@,listes-diff.inp-toulouse.fr 


\section{Communication}

\section{Statistical Analysis of the Influence of Some Trace Elements on Chunky Graphite Formation in Heavy Section Nodular Iron Castings}

\author{
JON SERTUCHA, JACQUES LACAZE, \\ SUSANA ARMENDARIZ, and PEIO LARRAÑAGA
}

To study the formation of chunky graphite $(\mathrm{CHG})$ in heavy section castings, 68 nodular cast irons of both pearlitic and ferritic grades were cast in cubic blocks $30 \mathrm{~cm}$ in edge. The volume fraction of the blocks affected by this degenerate graphite was quantified and related to the chemical analysis of the materials by means of a multivariate analysis. For the composition domain investigated, the effects of $\mathrm{Ce}, \mathrm{Cu}, \mathrm{La}, \mathrm{P}, \mathrm{Sb}$, and $\mathrm{Sn}$ were statistically established with a high $R^{2}$ correlation coefficient.

Although the influence of graphite degeneration on mechanical properties of ductile irons has been the subject of several technical works in recent decades, the present knowledge about the mechanisms that cause it is still limited. One of the most important examples among these degenerations is chunky graphite $(\mathrm{CHG})$, which was documented to have a detrimental effect on mechanical properties of nodular irons such as those used in the windmills industry. ${ }^{[1-3]}$ A noteworthy number of studies have focused on the influence of processing variables and of manufacturing conditions on CHG formation, ${ }^{[2,4,5]}$ while other works were aimed at determining the microscopic causes for the appearance of this defect. ${ }^{[4,6-9]}$ Regarding the processing variables, it was found that both inoculation $^{[1,5,10]}$ and low cooling rates ${ }^{[4,11,12]}$ promote $\mathrm{CHG}$ formation in nodular irons. The effect of inoculation, however, is controversial, as previously discussed. ${ }^{[5]}$ Furthermore, it has long been demonstrated that the chemical composition of melts has an important influence on this graphite degeneracy, which depends both on the main alloying elements such as $\mathrm{C}$ and $\mathrm{Si}$ through carbon equivalent ${ }^{[9,13]}$ and on trace elements such as $\mathrm{As}, \mathrm{Bi}, \mathrm{Pb}$,

JON SERTUCHA and PEIO LARRAÑAGA, Research Engineers, are with the Área de Ingeniería y Procesos de Fundición, AZTERLAN, 48200 Durango (Bizkaia), Spain. JACQUES LACAZE, Senior Scientist, is with CIRIMAT, Université de Toulouse, ENSIACET, BP 44362, 31030 Toulouse cedex 4, France. Contact e-mail: jacques.lacaze@ensiacet.fr SUSANA ARMENDARIZ, Engineer, is with TS Fundiciones, S.A. Pol. Sansinenea Erreka, 20749 Arroa-Zestoa (Gipuzkoa), Spain.
$\mathrm{Sb}, \mathrm{Te}$, or $\mathrm{Ti}^{\left[{ }^{[4,14]}\right.}$ The interplay between these metallic trace elements and rare earth additions through spheroidization and inoculation treatments was demonstrated. ${ }^{[4,15]}$ The effect of $\mathrm{Ce},{ }^{[16]} \mathrm{Sb},{ }^{[16,17]} \mathrm{Bi}$, and $\mathrm{Sb}^{[18]}$ was more particularly studied, and these elements were found to significantly affect this defect.

While it is recognized that very low levels of some elements may affect graphite degeneration in heavy-section nodular iron castings, very little quantitative information has been made available so far. The present work was designed to answer the need of quantitative prediction on the risk of $\mathrm{CHG}$ appearance in heavy-section castings. Chemical and metallographic data used in the present work were obtained from 68 cubic blocks $30 \mathrm{~cm}$ in side cast according to the experimental methodology previously described. ${ }^{[5]}$ The addition of specific alloying elements was performed in the ladle used to achieve the nodularizing treatment so as to have either pearlitic or ferritic grades. The chemical composition of the FeSiMg master alloy used for nodularizing was (wt pct) 42.2 to $45.0 \mathrm{Si}, 8.5$ to $9.1 \mathrm{Mg}, 2.5$ to $2.8 \mathrm{Ca}, 0.9$ to $1.1 \mathrm{Al}$, and 0.8 to 1.1 rare earths (RE). Postinoculation was carried out using a commercial inoculant ( 70 to $75 \mathrm{Si}, 3.2$ to $4.5 \mathrm{Al}, 0.3$ to $1.5 \mathrm{Ca}$, and 0.4 to $0.6 \mathrm{RE}$, wt pet). Chemical analysis of the cast materials was carried out on chips from the cast blocks by means of standard techniques. Table I gives the minimum and maximum values for all elements found to be significant in the present work. Among these casts, three of them were done for investigating the effect of nickel; they contained $0.03,0.53$, and 0.84 wt pet Ni. For these latter casts, the composition of the FeSiMg was (wt pct) 43.6Si, $6.3 \mathrm{Mg}, 1.1 \mathrm{Ca}, 0.6 \mathrm{Al}$, and $0.9 \mathrm{RE}$ and that of the inoculant $74.4 \mathrm{Si}, 1.2 \mathrm{Ca}, 4.1 \mathrm{Al}$, and $0.5 \mathrm{RE}$. All alloys were nearly eutectic, the pearlitic grades having carbon content in the range of 3.69 to $3.87 \mathrm{wt} \mathrm{pct}$ and the ferritic ones in the range of 3.61 to $3.82 \mathrm{wt}$ pct. The amount of $\mathrm{CHG}$ was quantified by the relative volume affected by this degeneration, $V_{V}(p c t)$, as estimated from an axial section of the blocks. ${ }^{[5]}$

Using JMP software, multivariate analysis was performed to assess the effect of individual elements on $\mathrm{V}_{\mathrm{V}}$ and for looking for the interaction between them. For this, the values of $\mathrm{V}_{\mathrm{V}}$ and of the content in Sb that were null were set to $10^{-4}$, so that the whole record of data could be processed. When performing the statistical analysis, only those parameters that were found to be statistically relevant for the available data set were selected. The shape of the residues $v_{S} \mathrm{~V}_{\mathrm{V}}$ suggested looking for a relation involving $\left(\mathrm{V}_{\mathrm{V}}\right)^{0.5}$ instead of $\mathrm{V}_{\mathrm{V}}$. The final expression at which we arrived is given as

$$
\begin{aligned}
\left(\mathrm{V}_{\mathrm{V}}\right)^{0.5}= & -3.1-1214.0 \cdot\left(1-64.6 \cdot w_{\mathrm{Sb}}-0.37 \cdot w_{\mathrm{Cu}}\right) \cdot w_{\mathrm{Sb}} \\
& -55.2 \cdot\left(1-4.8 \cdot w_{\mathrm{Sn}}-114.8 \cdot w_{\mathrm{Sb}}\right) \cdot w_{\mathrm{Sn}} \\
& +924.2 \cdot\left(1-64.4 \cdot w_{\mathrm{Ce}}\right) \cdot w_{\mathrm{Ce}} \\
& +605.0 \cdot\left(1-0.59 \cdot w_{\mathrm{Cu}}\right) \cdot w_{\mathrm{La}}+133.3 \cdot w_{\mathrm{P}}
\end{aligned}
$$

where $w_{\mathrm{i}}$ is the mass fraction of element $i$ as obtained from chemical analysis.

This relation with 12 terms gives a fit to experimental data with a quite high $R^{2}$ coefficient of 0.94 ; this is illustrated in Figure 1. 
Table I. Composition Range of the Most Significant Elements in the Studied Alloys (Weight Percent)

\begin{tabular}{lccccccrrr}
\hline $\mathrm{Si}$ & $\mathrm{Mn}$ & $\mathrm{Cu}$ & $\mathrm{P}$ & $\mathrm{S}$ & $\mathrm{Mg}$ & $\mathrm{Sb}$ & $\mathrm{Sn}$ & $\mathrm{Ce}$ & $\mathrm{La}$ \\
\hline 1.92 to & 0.09 to & 0.01 to & 0.010 to & 0.002 to & 0.023 to & 0.0 to & 0.0 to & 0.0005 to & 0.0005 to \\
2.41 & 1.04 & 1.11 & 0.039 & 0.015 & 0.055 & 0.010 & 0.14 & 0.0162 & 0.0074 \\
\hline
\end{tabular}

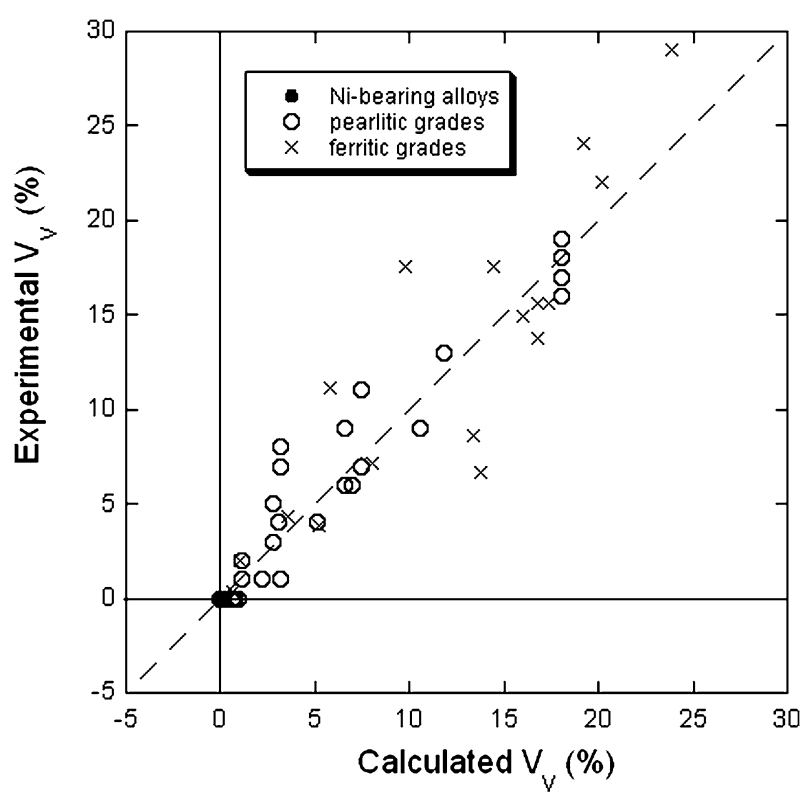

Fig. 1-Comparison of experimental and calculated values of $\mathrm{V}_{\mathrm{V}}$ using Eq. [1].

When $\mathrm{Sn}$ and $\mathrm{Sb}$ are known to decrease the risk of $\mathrm{CHG}$ formation, as indicated by the negative sign in front of the related terms, the cross-term $\mathrm{Sn}-\mathrm{Sb}$ is positive, indicating that these elements are counteracting each other at high enough level. As there is no stable compound between these elements at the temperature for processing and solidifying cast irons, this observation may be indicative of more complex interactions through other elements present in the melts or at the graphite liquid interface. As for $\mathrm{Cu}$, this element was reported to decrease the risk of chunky appearance, ${ }^{[19]}$ but the present analysis shows this beneficial effect to be related to the presence of La while a negative cross-effect, i.e., an increase of $\mathrm{V}_{\mathrm{V}}$, is associated with its association with $\mathrm{Sb}$. Again, there is no compound stable at high enough temperature in the binary $\mathrm{Cu}$-La and $\mathrm{Cu}-\mathrm{Sb}$ systems that could help in understanding this result. These cross-effects are thus certainly worthy of further investigations.

The presence of a square term for $\mathrm{Sb}, \mathrm{Sn}$, and $\mathrm{Ce}$ in Eq. [1] suggests these elements could show an optimum value within the composition range investigated. The effect of each of these three elements on the predicted $\left(\mathrm{V}_{\mathrm{V}}\right)^{0.5}$ values is illustrated in Figure 2. The curves in this figure were obtained using Eq. [1] by varying the content of either $\mathrm{Sb}, \mathrm{Sn}$, or Ce with all other elements set at the minimum indicated in Table I (Figure 2(a)), at the mid of the composition range (Figure $2(b)$ ) or at the maximum (Figure 2(c)). Note that a tenth of the Sn content was used in plotting for easier reading of the figures.

Figure 2(a) shows that a cast iron with a composition at the minimum of the range in each element, and thus quite pure, would not present $\mathrm{CHG}$, while an alloy with all elements at the mid (respectively, maximum) level in Table I would be slightly (respectively, significantly) affected.

It is seen in the graphs in Figure 2 that cerium addition has the same effect whatever the content in other elements. Cerium is detrimental for addition up to $0.008 \mathrm{wt}$ pct and shows a healing effect above that percentage. The effect of cerium in increasing the amount of $\mathrm{CHG}$ when added at low and intermediate levels agrees with reports on heavy section castings. The present work suggests that, at higher level, cerium becomes beneficial, and this could possibly be related to the fact that it increases eutectic undercooling, ${ }^{[16]}$ thus favoring spheroidal growth.

$\mathrm{Sb}$ and $\mathrm{Sn}$ present the same behavior, decreasing CHG when added at low level in pure or slightly impure cast irons, but it is seen that they both would become detrimental in strongly contaminated alloys. The optimum addition of $\mathrm{Sn}$ is about $0.1 \mathrm{wt}$ pet for a pure cast iron (Figure 2(a)) and about 0.05 for a slightly impure one (Figure 2(b)). These optimum values are similar to the maximum allowable $\mathrm{Sn}$ content at $0.13 \mathrm{wt}$ pct reported in Lux's review. ${ }^{[20]}$ As for $\mathrm{Sb}$, it should be noted that degenerate graphite due to $\mathrm{Sb}$ in usual castings has most often been reported as spiky graphite and not $\mathrm{CHG}$. On the other hand, its beneficial effect in heavy-section castings was associated to $\mathrm{Sb}$ binding $\mathrm{Ce}$ in $\mathrm{Ce}-\mathrm{Sb}$ compounds. ${ }^{[4]}$

A close examination of Figure 1 shows that the investigated pearlitic grades present, on the whole, lower amounts of $\mathrm{CHG}$ than do ferritic grades. However, these pearlitic grades were obtained by adding one of either $\mathrm{Cu}, \mathrm{Mn}$, or $\mathrm{Sn}$, but never both of them. Thus, Figure 2(c), where the predicted $V_{V}$ values are higher than in Figures 2(a) and (b), is somehow an extrapolation of the present correlation in a composition range that has not been investigated.

Finally, the most striking observation made when looking at Eq. [1] concerns the role of P. As a matter of fact, it has never been reported explicitly as leading to $\mathrm{CHG}$ formation, as shown here, but is known to have a detrimental effect on graphite shape,${ }^{[20,21]}$ much like $\mathrm{Sb}$, as mentioned previously. However, a statistical analysis made by Javaid and Loper ${ }^{[4]}$ showed the same trend as here, though the authors did not comment on this finding. Further, Reynaud and Parent-Simonin ${ }^{[15]}$ reported on a P spike around $\mathrm{CHG}$ cells, again without giving any hint about its meaning and consequences. This effect of $\mathrm{P}$ does not seem to relate directly to the fact that it may easily 


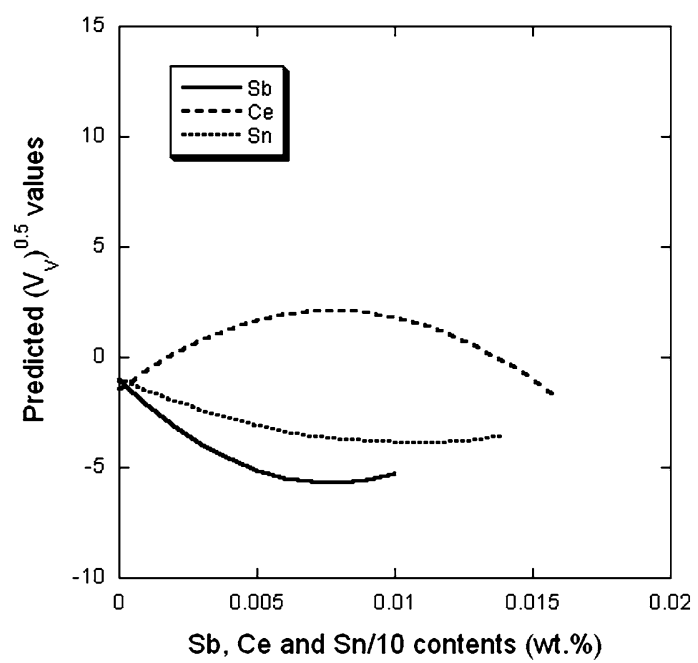

(a)

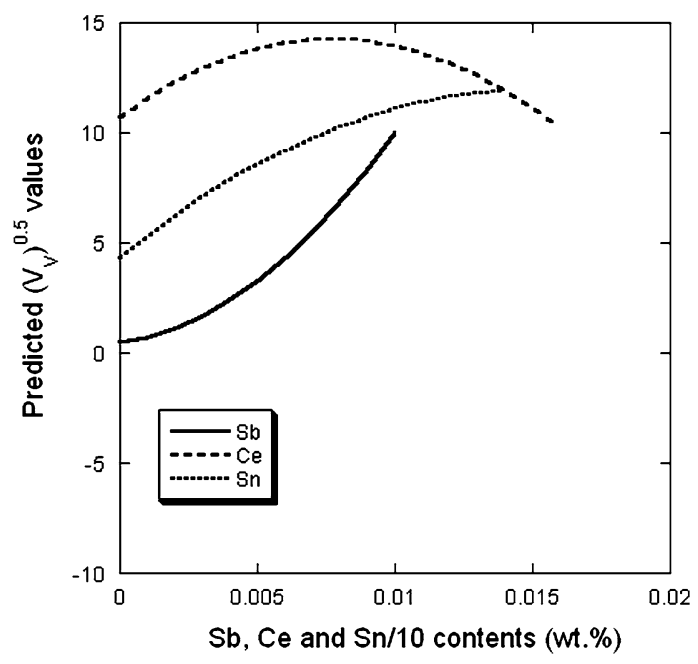

(c)

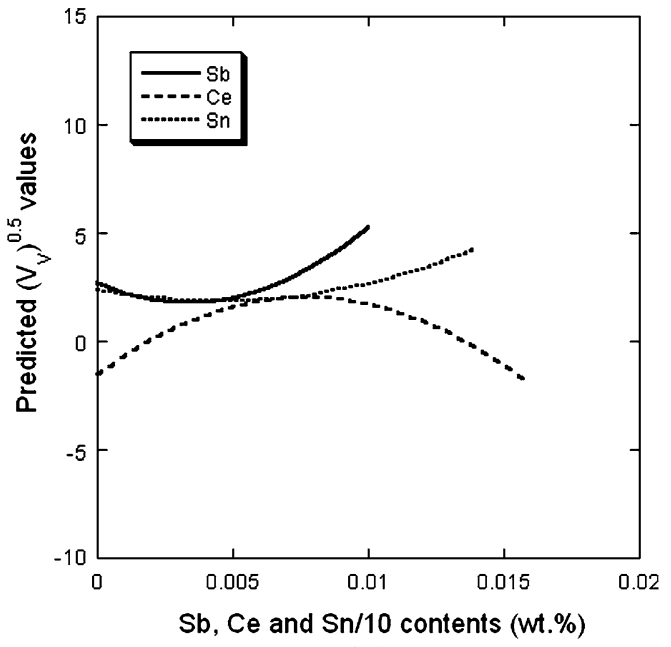

(b)

Fig. 2-Predicted change in $\mathrm{CHG}$ content $\left(\mathrm{V}_{\mathrm{V}}\right)^{0.5}$ with addition of $\mathrm{Sb}, \mathrm{Ce}$, and $\mathrm{Sn}$. For easier reading, the tenth of the addition in $\mathrm{Sn}$ was used and the curves were limited to the investigated composition range for each of these three elements. $(a)$ through $(c)$ were obtained for, respectively, the minimum, the mid, and the maximum of the composition range of other elements.

combine with $\mathrm{Ce}$ to form $\mathrm{CeP}$ compound, which was observed ${ }^{[4,22]}$ One possible explanation, which should be investigated further, is that the addition of $\mathrm{P}$ leads to the dissolution of some Ce-bearing compounds that are less stable than $\mathrm{CeP}$ and contain detrimental elements that can get dissolved again in the melt.

The present analysis offers a means to evaluate the risk for $\mathrm{CHG}$ formation in heavy-section castings on the basis of chemical contents in a limited number of elements. It is clear, however, that a more extensive study would be necessary to account for other low level elements that are known to modify graphite growth behavior.

\section{REFERENCES}

1. Z. Ignaszak: Int. J. Cast Met. Res., 2003, vol. 16, pp. 93-97.

2. R. Källbom, K. Hamberg, and L.E. Björkegren: in Proc. Gjutdesign 2005 Final Seminar, VTT Technical Research Centre of Finland, Espoo, 2005, pp. 1-25.
3. M. Gagné and C. Labrecque: AFS Trans., 2009, vol. 117, pp. 561-71.

4. A. Javaid and C.R. Loper, Jr.: AFS Trans., 1995, vol. 103, pp. $135-50$.

5. I. Asenjo, P. Larrañaga, J. Sertucha, R. Suárez, J.M. Gómez, I. Ferrer, and J. Lacaze: Int. J. Cast Met. Res., 2007, vol. 20, pp. 319-24.

6. E.N. Pan, C.N. Lin, and H.S. Chiou: AFS Trans., 1995, vol. 103, pp. $265-73$.

7. B.C. Liu, T.X. Li, Z.J. Rue, X.Y. Yang, E.Q. Huo, and C.R. Loper, Jr: AFS Trans., 1990, vol. 98, pp. 753-57.

8. E. Campomanes: Giesserei, 1978, vol. 65, pp. 535-40.

9. T.C. Xi, J. Fargues, M. Hecht, and J.C. Margerie: Mater. Res. Soc. Symp. Proc., 1985, vol. 34, pp. 67-76.

10. S.I. Karsay and E. Campomanes: AFS Trans., 1970, vol. 58, pp. 85-92.

11. R. Källbom, K. Hamberg, M. Wessen, and L.E. Björkegren: Mater. Sci. Eng. A, 2007, vols. 413-414, pp. 346-51.

12. H.W. Hoover, Jr.: AFS Trans., 1986, vol. 102, pp. 601-08.

13. J. Lacaze, S. Armendariz, P. Larrañaga, I. Asenjo, J. Sertucha and R. Suárez: Mater. Sci. Forum, 2010, vols. 636-637, pp. 523-30.

14. H. Löblich: Giesserei, 2006, vol. 93, pp. 28-41.

15. A. Reynaud and S. Parent-Simonin: Fonderie, Fondeur d'aujourd'hui, 1990, vol. 91, pp. 17-25.

16. P. Larrañaga, I. Asenjo, J. Sertucha, R. Suarez, I. Ferrer, and J. Lacaze: Metall. Mater. Trans. A, 2009, vol. 40A, pp. 654-61. 
17. P. Larrañaga, I. Asenjo, J. Sertucha, R. Suarez, I. Ferrer, and J. Lacaze: Int. J. Cast Met. Res., 2009, vol. 22, pp. 192 95.

18. E.N. Pan and C.Y. Chen: AFS Trans., 1996, vol. 104, pp. 845-58.

19. N. Carter and R. Barton: BCIRA J., 1966, vol. 14, pp. 252-63.
20. B. Lux: Giessereiforschung, 1970, vol. 22, pp. 65-81.

21. ASM Specialty Handbook, ASM International, Materials Park, OH, 1996

22. I. Asenjo, J. Lacaze, P. Larrañaga, S. Méndez, J. Sertucha and R. Suarez: Key Eng. Mater., 2011, vol. 457, pp. 52-57. 